This item was submitted to Loughborough's Research Repository by the author.

Items in Figshare are protected by copyright, with all rights reserved, unless otherwise indicated.

\title{
From places to flows? Planning for the new 'regional world' in Germany
}

PLEASE CITE THE PUBLISHED VERSION

http://www.regionalstudies.org/

\section{PUBLISHER}

Regional Studies Association @ $\odot$ The authors

\section{VERSION}

AM (Accepted Manuscript)

\section{LICENCE}

CC BY-NC-ND 4.0

\section{REPOSITORY RECORD}

Harrison, John, and Anna Growe. 2019. "From Places to Flows? Planning for the New 'regional World' in Germany”. figshare. https://hdl.handle.net/2134/9187. 
This item was submitted to Loughborough's Institutional Repository (https://dspace.lboro.ac.uk/) by the author and is made available under the following Creative Commons Licence conditions.

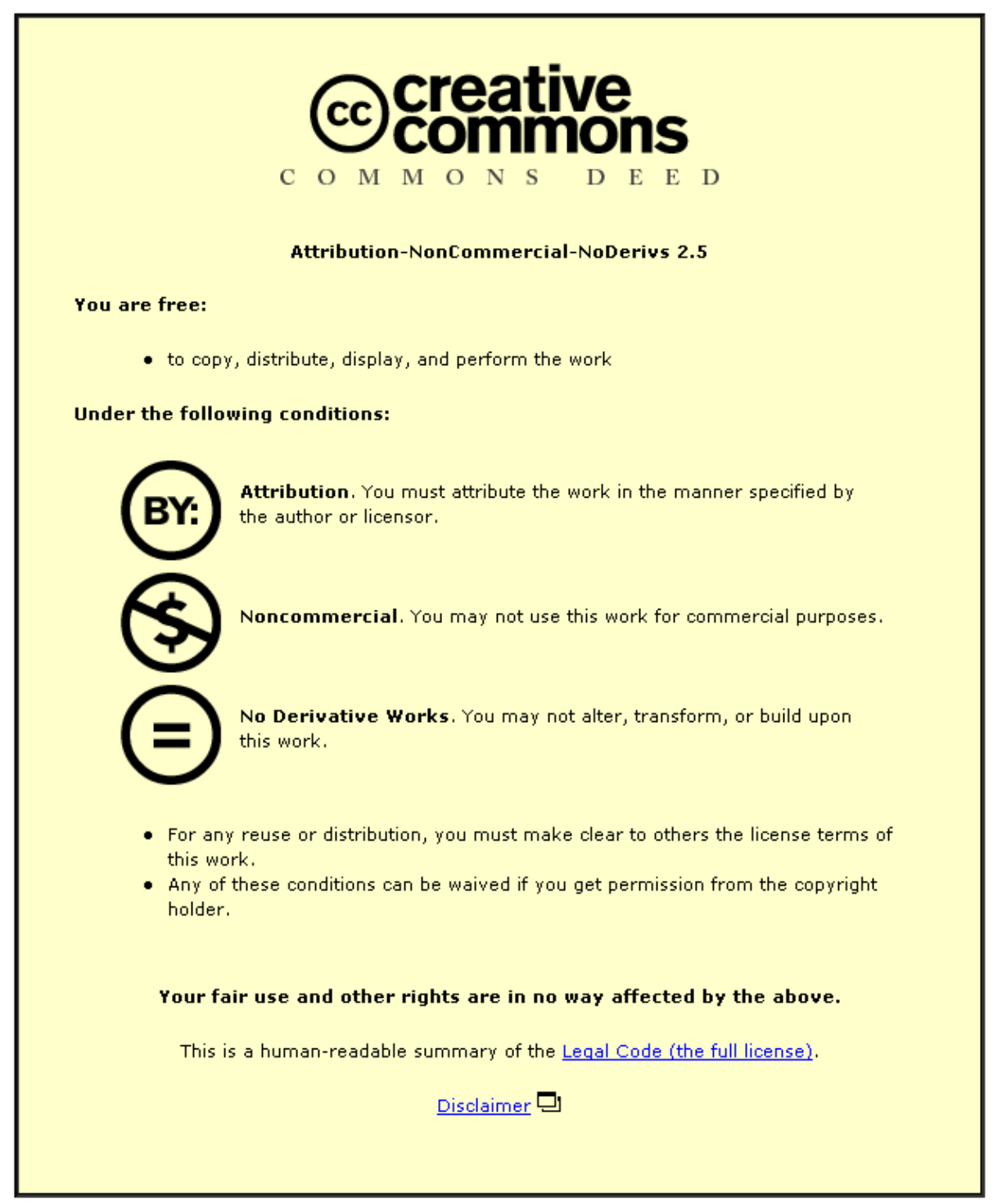

For the full text of this licence, please go to: http://creativecommons.org/licenses/by-nc-nd/2.5/ 


\section{From places to flows? Planning for the new 'regional world' in Germany}

John Harrison and Anna Growe

\section{Introduction: Regional World(s)}

The last two decades have been dominated by discourses describing a resurgence of regions. Part and parcel of this discourse has been how leading proponents of what is labelled the 'new regionalism' documenting how the collapse of Atlantic Fordism and onset of globalization is seeing the region challenge the nation-state as the 'natural economic zone' (Ohmae, 1995), alongside its primacy as the site/scale at which economic management is conducted, social welfare delivered, and political subjects are identified by their national citizenship. Captivating academics (interested in interpreting capitalism's new economic and spatial form) and policymakers (casting increasingly 'envious eyes' toward the regional zones of the Atlantic and European growth economies) alike, the new regionalist orthodoxy of the mid-to-late-1990s saw the region canonized in academic and political discourse as a functional space for economic planning and governance. Nevertheless, despite largely unprecedented levels of intellectual and political energy being invested in the conviction that regions are central to modern life, critics of the new regionalism generally, and normative claims relating to the formation of the 'regional world' in particular, responded to the blind faith in which regions were being championed to expose a series of deep-rooted problems, contradictions, and challenges. Of paramount concern among critics has been the exposition of widespread conceptual amnesia when it comes to defining the region. Often assumed, rarely defined, it is hard to dispute how the region remains an 'object of mystery' (Harrison, 2006), an 'enigmatic concept' (MacLeod and Jones, 2007), and a 'complicated category' (Paasi, 2010) for those trying to engage with this most durable of constructs. Even in the work of the political scientist, Michael Keating, one of the most consistently insightful scholars on this aspect of the new regionalism, while it is acknowledged that regions take various forms (e.g. administrative, cultural, economic, governmental, historical) his focus, and that of those advancing claims we were now living in a 'regional world', became narrowly focused and remained principally with regions as actual or potential subnational political units - be they administrative or governmental.

In stark contrast to the period of new regionalist orthodoxy, the latest rounds of global restructuring, alongside the European Commission's efforts to regularise land use planning regimes and remove international and interregional anomalies in the way economic development is regulated, are resulting in an ever expanding assemblage of new interregional, intercity and transnational collaborative initiatives in economic development and spatial planning. Extending across Europe, the emergence and institutionalisation of city-regions, cross-border regions, European Metropolitan Regions, and polycentric mega city-regions sees the regional map of Europe no longer simply divided by the familiar NUTS II (Nomenclature of Territorial Units for Statistics) administrative regions but recording the construction of new relationally-networked regional spaces. Noting how many of these new regional spaces cross-cut the territorial map which prevailed through much of the twentieth century, in many ways what we are observing amounts to a new regionalism version 2.0 which is currently sweeping across Europe. 
All of which can be seen to suggest that as we enter deeper into globalization what we are witnessing is the emergence of a new relationally-constituted 'regional world' (cf. Storper, 1997), where capital accumulation and governance is "about exercising nodal power and aligning networks in one's own interest, rather than about exercising territorial power ... [for] there is no definable territory to rule over" (Amin, 2004, p.36). But at the same time it prompts the need to ask searching questions over the degree to which the production of these 'non-standard' regional spaces is serving to replace territorially-bounded regions as part of some zero-sum game or either/or logic. What thinking like this leads to is an understanding that how one interprets the emergence of these new regional spaces, in particular the way they complement, overlap, compete, or contradict with existing sociospatial configurations is crucial not just for helping us as 'regional' researchers better understand how we should interpret regions and approach the analysis of regional spaces, but the degree to which these new configurations produce progressive and effective spatial policies. With this in mind, our paper examines recent endeavours to construct a new spatial map of Germany according to the need to think state space relationally, emphasise 'spaces of flows' approaches, and privilege cities in globalization.

\section{Putting theory into practice: German planning philosophy}

\section{Stage 1: European Metropolitan Regions and the regionalisation of spatial planning}

The task of positioning major cities and regions within European and global circuits of capital accumulation saw spatial planning in Germany experience resurgence in the 1990s. Interesting to note was how Germany used its status as a state with a polycentric urban system to argue that promoting the strategic importance of 'metropolitan regions' was necessary given spatially concentrated economies grow faster in globalization, but that this could actually help meet the longstanding and principled pursuit of spatial equivalence. Published in 1995, the 'Federal Action Plan' identified six agglomerations (Berlin/Brandenburg, Hamburg, Munich, Rhine-Main, Rhine-Ruhr and Stuttgart) of 'superior' strategic importance. These were to be known as 'European Metropolitan Regions' (BmBau, 1995) and such was the perceived value of being identified part of this 'new elite' that a further five agglomerations (Bremen-Oldenburg, Halle/Leipzig-Sachsendreieck, Hanover-Braunschweig-Göttingen-Wolfsburg, Nuremberg, and Rhine-Neckar) were motivated to be admitted to this new politically constructed top hierarchy within the German urban system.

With so much intellectual and political energy being invested in support of European Metropolitan Regions, their ascendancy to become the dominant discourse in Germany's urban and regional political-economy was clear for all to see. Yet the fact that these metropolitan regions are not politico-administrative bodies was serving to ensure their function remained one of 'framing' a new discourse - around the need to maintain and develop the metropolitan functions of a select number of urban agglomerations - rather than enabling them to act on this. In effect, this newly constructed hierarchy of cities provides urban and regional stakeholders with a platform to campaign and put pressure on state, national, and European institutions to recognise their superior strategic importance within spatial development policies. Nevertheless, with the metropolitan region discourse emerging to challenge the former dominant idea of a 'regional world' based on regions as actual or potential subnational political units - an idea fast losing its academic and political appeal the next stages in the development of this discourse were posing a number of political headaches for its architects. Not least of their problems is how to manage the many contradictions, overlaps, and 
competing tendencies resulting from European Metropolitan Regions appearing alongside, rather than replacing, existing forms of state scalar organisation.

Stage 2: Redrawing the boundaries of the German space economy - constructing a new spatial map

Following a two-year technical and political discussion process, 30 June 2006 saw the Federal Government adopt the Leitbilder - the joint development strategy for the cities and regions of Germany. The Leitbilder identifies three main types of area: (1) European Metropolitan Regions, the same eleven which emerged from the 1992 guidelines; (2) dynamic growth areas outside metropolitan regions, those dynamic growth clusters, cities and locational areas outside the immediate metropolitan spheres of influence, but which are exhibiting signs of independent, sustainable profiles based on endogenous growth; and (3) areas with need for stabilization, that is, rural and old industrial areas which are often peripheral locations, located close to borders, and fall in-between areas of growth. More important than this, what we now had is a German space economy that is no longer simply being discussed in relational terms, but the spatial map of the economy now being represented and defined as a web of relational connectivity and networked 'space of flows' (Figure 1) - developments that could amount to a trans-region and relationallynetworked embryonic national spatial plan based on interacting, but hierarchically differentiated, city-regions.

Figure 1. Concept: Growth and Innovation (BMBVS/BBR, 2006: 13) 


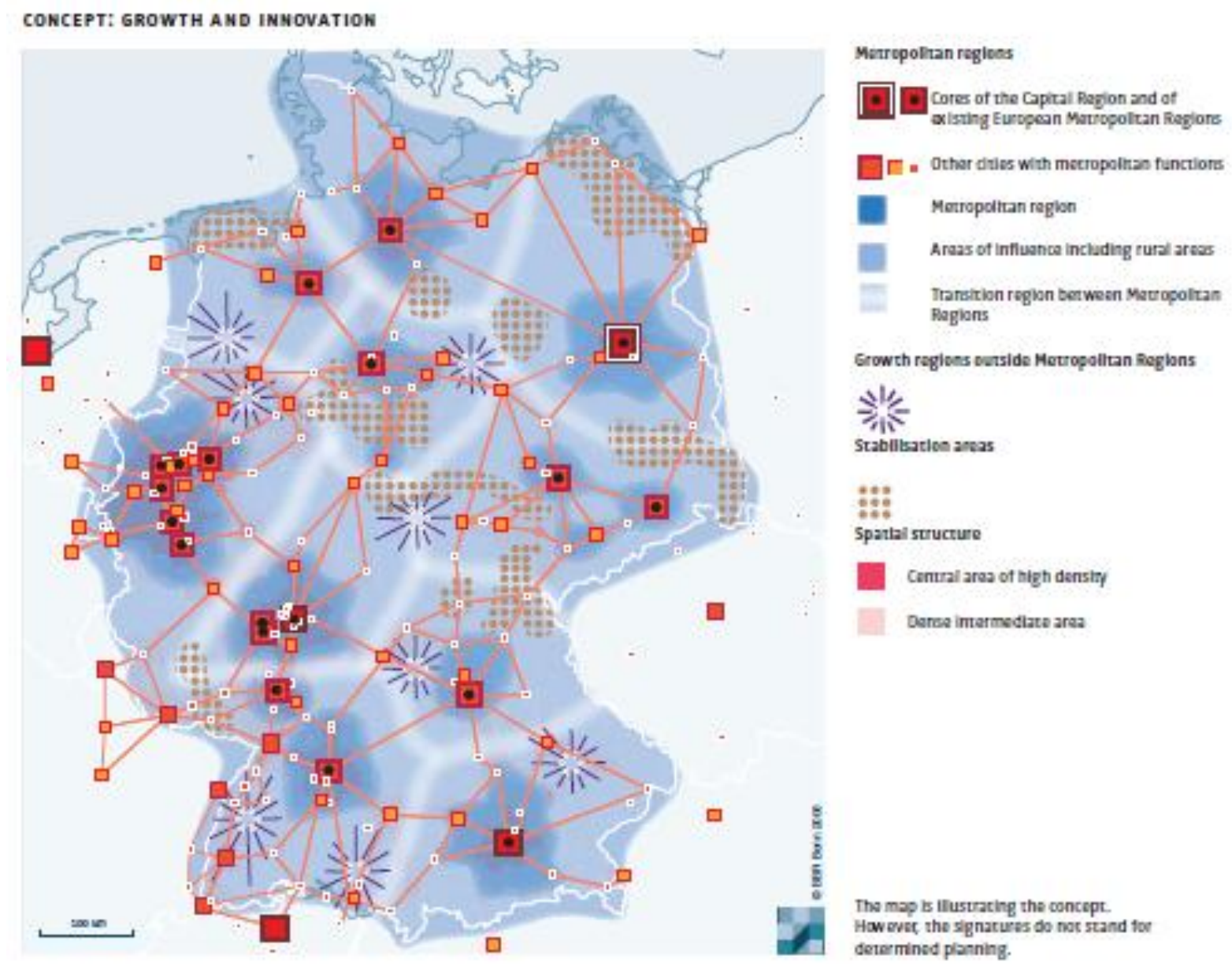

To this end, a number of important observations can be made.

1. First and most obvious is how the territorial boundaries of the politico-administrative Länder are nowhere to be seen. What we see instead is an idealised structure of more networked forms of regional cooperation and collaboration on a regional level. Identified as 'large scale areas of responsibility', each area is shown to comprise an existing metropolitan region, and a wider 'area of influence'. Of particular note is how the boundary lines remain ambiguous and neither do they correspond to any known administrative or functional boundary.

2. Second, while the 1990s guidelines were spatially selective in prioritising metropolitan regions of superior strategic importance, those areas which were clearly at the fringes or fell in-between or outside the scope of this policy discourse before 2006 are now all included as either an area of influence, growth region outside metropolitan regions, or stabilisation area. In a move that some might be appear at first glance to be more progressive given its move toward spatial inclusivity, it is important not to forget the clear evidence of hierarchical differentiation at play here.

3. Third, we see three different 'city-region' models/definitions deployed in the same map: the city-region as agglomeration, to identify existing metropolitan regions and their core; cityregions as a scale to present this idealised structure of more networked forms of regional cooperation and collaboration at a federal level; and interestingly, city-regions as hub and spokes to connect metropolitan regions to other cities with metropolitan functions in the 
first instance, but also identify growth areas outside metropolitan regions. What we take from this is that the city-region concept is being bent to fit particular needs and to serve a specific political purpose, that being, the need to balance their promotion of metropolitan regions with managing uneven spatial development. But what we can also identify is how the chaotic nature of the city-region concept is becoming a necessary tool in the armoury of policy elites. In effect, each model of city-region development is used here to manage the contradictions and competing tendencies resulting from attempting to construct a new spatial map of city-regions.

4. Albeit the boundaries of the Länder are noticeably absent from this map, the fourth point is that one line of political and administrative importance remains - the German national border. What this suggests is that although the Federal State are accepting of the need to think beyond the narrow confines of territorially bound politico-administrative units within the national context, albeit there is some suggestion of spillover into neighbouring countries in the spatial map, there is an unwillingness at this point to consider such practices when it involves collaboration with areas that lie beyond the national border.

This final point is important in the context of the broader debates around city-regions and the construction of a new relationally-constituted 'regional world' because it also alerts us to the fact that as presented here, the concepts of 'European Metropolitan Region' and 'cross-border region' appear mutually exclusive in the German policy discourse. Nevertheless, there have not been moves of late to incorporate cross-border regions into debates over European Metropolitan Regions, in what we might usefully understand to the third stage in transition towards a relational viewpoint on the German space economy.

With this in mind the paper explores the possibility of cross-border metropolitan regions before offering a few conducing comments. Here we argue the example of Germany is particularly revealing in extending our understanding of how new (city) regional spaces are constructed politically, but more particularly, how the ambiguity of the region/city-region concepts is being used as a key some might say necessary - political tool in enabling the Federal State to manage the contradictions, overlaps and competing tendencies resulting from their attempt to present territorial and relational approaches to regions and regionalism as complementary alternatives. The upshot of all this is that understanding how these new regional spaces are constructed politically is going to be more, not less, important in the future.

\section{References:}

Amin A (2004) Regions Unbound: Towards a New Politics of Place. Geografiska Annaler B, 86: 33-44.

BmBau (Bundesministerium für Raumordnung, Bauwesen und Städtebau) (1995) Raumordnungspolitischer Handlungsrahmen - Beschluss der Ministerkonferenz für Raumordnung in Düsseldorf am 8 März. Bonn.

BMVBS/BBR (Bundesministerium für Verkehr, Bau- und Stadtentwicklung/ Bundesamt für Bauwesen und Raumordnung) (2006) Leitbilder und Handlungsstrategien für die Raumentwicklung in Deutschland. Berlin.

Harrison J (2006) Re-Reading the New Regionalism: A Sympathetic Critique. Space and Polity 10: 2146. 
MacLeod G, Jones M (2007) Territorial, Scalar, Networked, Connected: In What Sense a 'Regional World'? Regional Studies 41: 1177-91.

Ohmae K (1995) The End of the Nation State: The Rise of Regional Economies. Harper Collins: London.

Paasi A (2010) Regions are Social Constructs, But Who or What 'Constructs' Them? Agency in Question. Environment and Planning A 42: 2296-2301.

Storper M (1997) The Regional World: Territorial Development in a Global Economy. Guildford Press: New York. 